\title{
Os modelos no Ensino de Ciências: Reações de estudantes ao utilizar um objeto-modelo mecânico concreto analógico didático (OMMCAD)
}

Models in science education: Student reactions when using an didactic analog concrete mechanical model object (OMMCAD).

\author{
Fernando Siqueira da Silva*1@, Francisco Catelli2@ \\ ${ }^{1}$ Universidade Federal do Pampa, Rua Alberto Benevenuto, n. 3200, São Borja, RS, Brasil \\ ${ }^{2}$ Universidade de Caxias do Sul, Rua Francisco Getúlio Vargas, n. 1130, Caxias do Sul, RS, Brasil
}

\begin{abstract}
Recebido em 13 de setembro de 2019. Revisado em 08 de outubro de 2019. Aceito em 31 de outubro de 2019
Neste manuscrito apresentamos a noção de objeto-modelo mecânico concreto analógico didático (OMMCAD), um tipo de modelo didático nascido na fusão da epistemologia Bungeana dos modelos (modelos científicos) com a didática das ciências (modelos didáticos), desenvolvido para fins de ensino-aprendizagem da temática astronômica do a) movimento aparente do Sol, b) das diferentes direções do nascimento do Sol ao longo do ano e c) da duração aproximada do "dia claro" para qualquer região da Terra. Alguns resultados do nosso trabalho de modelização realizado com 11 alunos do último ano do Ensino Médio são divulgados. Apresentamos também a visão de alguns educadores em ciências, a nível internacional, que trabalham com modelização na escola, isto é, com ações práticas de elaboração, de confecção e de exploração de modelos para representação da realidade; atividades criativas que são propulsoras de uma educação científica escolar. Os resultados indicam fortes indícios de que o OMMCAD pode ser utilizado como um material suplementar ao livro didático escolar, contribuindo para a superação de um dos desafios para o ensino de ciências na atualidade: as insuficiências do livro didático.
\end{abstract}

Palavras-chave: Modelização, Objeto-modelo didático, Material didático, Movimento aparente do Sol.

In this manuscript we present the notion of didactic analog concrete mechanical model object (OMMCAD), a type of didactic model born of the fusion of the Bungeana epistemology of models (scientific models) with the didactics of sciences (didactic models), developed for teaching-learning purposes of the astronomical theme of the a) apparent movement of the Sun, b) of the different directions of the sun's rise throughout the year and c) the approximate duration of the "clear day" for any region of the Earth. Some results of our modeling work with 11 senior students are disclosed. We also present the insight of some science educators at the international level who work with modeling at school, that is, with practical actions to elaborate, make and explore models to represent reality; creative activities that propel a school science education. The results indicate strong evidence that OMMCAD can be used as supplemental material to the school textbook, contributing to overcoming one of the challenges for science education today: the insufficiencies of the textbook.

Keywords: Modeling, Didactic model object, Material didactic, Apparent sun movement.

\section{Introdução}

Um número significativo de pesquisas em educação em ciências, em especial, no Ensino de Astronomia, há algum tempo vêm demonstrando que os alunos da Educação Básica trazem para a escola concepções prévias a respeito do Universo e do Sistema Solar [1-9], são ideias de senso comum bastante resistentes a mudanças e que, normalmente, encontram-se em desacordo com as concepções científicas. Acredita-se que uma das causas para a permanência destas concepções intuitivas se deve à falta de materiais didáticos específicos e atualizados, sendo consensual entre os pesquisadores a opinião de que os livros

*Endereço de correspondência: fernandosiqueiradasilva@gmail.com didáticos de ciências e geografia (na maioria dos casos o único material utilizado nas escolas) mesmo depois de reformulações promovidas pelo Ministério da Educação (MEC) ainda continuam apresentando problemas conceituais em seu conteúdo [9], fato que vem denunciando o livro didático como uma fonte problemática para o Ensino de Astronomia.

Em nossa pesquisa, realizada com 11 alunos do último ano do Ensino Médio de uma escola da rede particular de Caxias do Sul (RS), envolvendo a temática das concepções prévias à respeito do movimento aparente do Sol [10], identificamos que boa parte das ideias de senso comum que surgiram estavam ligadas a um ensino escolar anterior, orientado pelas representações inadequadas dos livros didáticos, representações que, por exemplo, têm 
fortalecido a falsa crença já bastante difundida entre alunos e até mesmo entre os professores de que o Sol nasce "sempre" no Leste e se põe "sempre" no Oeste [4] e; a uma outra falsa crença de que a principal causa das estações do ano é consequência da maior ou menor proximidade da Terra ao Sol [2]. A observação dessas concepções prévias no decorrer do nosso estudo nos fez perceber que é preciso ir além dos livros didáticos, que em muitos casos podem estar servindo como verdadeiros obstáculos ao conhecimento.

Foi percebendo a necessidade da superação das insuficiências do livro didático em relação a temática astronômica do movimento aparente do Sol, especificamente, que construímos um objeto-modelo mecânico concreto analógico didático (OMMCAD). Um tipo de modelo didático nascido na fusão da epistemologia Bungeana dos modelos [11] com a didática das ciências [12, 13] que foi desenvolvido para fins de ensino e aprendizagem da temática do: a) movimento aparente do Sol, b) das diferentes direções do nascimento do Sol ao longo do ano e c) da duração aproximada do "dia claro" para qualquer região da Terra ${ }^{1}$ Um modelo que foi submetido ao processo da transposição didática, retirando fundamentos da instância do saber sábio (Ciência) para a instância do saber a ensinar (Ensino de Ciências) [14] e que agora pretende ser um material didático suplementar ao livro didático, auxiliando alunos e professores no entendimento e na compreensão, na explicação e na previsão de alguns aspectos da realidade.

Neste manuscrito vamos apresentar a noção de OMMCAD que utilizamos em nosso estudo, trazendo alguns resultados alcançados durante as atividades práticas de modelização com nosso grupo de alunos. Antes, pretendemos trazer alguns aspectos da noção de modelo na Ciência e no Ensino de Ciências, dando destaque aos modelos científicos como objetos de ligação entre as teorias e a realidade, verdadeiros produtos da ciência, sempre em processo, e que transpostos para uma moldura didática (modelos didáticos) podem contribuir para a superação de importantes desafios no Ensino de Ciências como, por exemplo, a superação das insuficiências do livro didático em relação à temática astronômica [15].

\section{Dos modelos na Ciência aos modelos no Ensino de Ciências: o caso do OMMCAD}

Acreditamos que a noção de modelo científico é essencial para a Ciência assim como deveria ser a noção de modelo didático para o Ensino de Ciências, não sendo possível conceber a noção de modelo didático sem antes desenvolvermos uma ideia sobre os modelos científicos e as suas relações com as teorias e com a realidade. Essa é uma

1 A expressão "dia claro" significa o intervalo de tempo que o Sol fica acima do horizonte. observação importante, pois, no processo da transposição didática são os modelos científicos que emprestam alguns de seus fundamentos aos modelos didáticos, que por sua vez aparecem em uma nova linguagem, mais intuitiva, mais próxima da linguagem dos alunos iniciantes. Em um manuscrito anterior já havíamos elaborado um breve cenário a respeito do conceito de modelo na Ciência [16], onde evidenciamos alguns traços da sua primeira aparição na investigação científica até chegarmos na identificação de sua concepção mais contemporânea. Embora, é bem verdade, num cenário limitado às ciências formais e factuais, nesses escritos argumentamos que não há, atualmente, uma linguagem única ou universal para a noção de modelo, um objeto que carrega por trás de seu desenvolvimento histórico e epistemológico um processo de complexidade. Atualmente, no debate científico, parece-nos que mais importante do que saber o que é um modelo é identificar o que os modelos fazem e para o que eles servem (ou a quem eles servem). Esse é um assunto que vamos resgatar de forma muito breve, a seguir, a fim de mais adiante fundamentarmos o conceito de objeto-modelo mecânico concreto analógico didático (OMMCAD) que desenvolvemos para o ensino da temática astronômica, anunciada anteriormente em a), b) e c).

\subsection{Os modelos na Ciência: fundamentos da epistemologia Bungeana dos modelos}

Percebemos que a história e a filosofia da ciência em torno da noção de modelo é algo recente se comparada a origem histórica desse vocábulo. A origem etimológica da palavra modelo ocorreu ainda na idade média, de onde do latim modulus passou para o francês moule (molde), do inglês mould para o alemão mold, aparecendo depois no período Renascentista Italiano, entre artesãos, pedreiros e arquitetos como modello, em francês modèle, em inglês model e em alemão modell, numa conceituação bastante próxima àquela da escala, entendido entre os séculos XV e XVI como "a medida arbitrária utilizada para determinar relatórios de proporção entre as partes de uma obra de arquitetura" [17, p.92]. A noção de modelo emergiu assim das áreas artísticas e técnicas, e com sucessivas adaptações de significado alcançou o debate científico só em meados de 1860, onde surgiram os modelos mecânicos e as analogias em física, em 1920 os modelos semânticos da lógica matemática, depois mais em meados de 1950 os modelos matemáticos, objetos-modelos e seus modelos teóricos, evoluindo em meados de 1980 para uma noção intrinsecamente ligada aos programas computacionais, deixando de ser para a Ciência uma preocupação de ordem ontológica (o que é um modelo?) passando a ter uma preocupação de ordem funcional (o que faz um modelo?).

Mas o que é um modelo? Durante o processo de desenvolvimento da noção de modelo na Ciência parecem ter ocorrido algumas discordâncias entre filósofos da ciência 
e cientistas, os quais buscavam por uma linguagem única, segura e precisa para responder a essa pergunta; e uma resposta foi brilhantemente dada pelo desenvolvedor da Teoria do Sistema Geral, o engenheiro e epistemólogo francês, Jean-Louis Le Moigne [18], segundo seus mais distintos significados um modelo pode ser: um desenho, um diagrama, um esboço, uma ilustração, um objeto concreto (OMMCAD), uma estrutura matemática (modelo simbólico), um software de computador, uma cópia de alguma coisa (modelo icônico). No sentido epistemológico o modelo pode ser equiparado a qualquer estrutura, seja concreta ou abstrata, que visa de algum modo representar aspectos de uma determinada realidade, fato ou coisa [11], ou fenômeno [18], mas sem nunca a alcançando completamente.

O modelo adquiriu então essa função de representação da realidade e independente da sua estrutura ser concreta ou abstrata, tangível ou intangível, visualizável ou inteligível, icônica ou simbólica, o que realmente o define como um bom ou mau modelo dependerá da sua estrutura teórica, ou melhor, do modelo teórico que lhe dá suporte [11]. Na Ciência, os modelos aparecem como idealizações simplificadas da realidade, sempre envoltos em teorias e não devem ser confundidos com a realidade em si, pois apenas alguns de seus aspectos, alguns de seus referentes são por ele representados, existindo sempre certos elementos da realidade que escapam ao modelo e sua teoria subjacente. Assim, mais importante do que encontrar uma única e precisa definição para o conceito de modelo foi a necessária identificação da sua funcionalidade $[19$, p. 294] não sendo fácil conhecermos a realidade sem antes dela construirmos um modelo. Portanto, precisamos entender que os modelos científicos, enquanto simplificações e idealizações da realidade, são verdadeiras criações do pensamento, e como tal são necessariamente instrumentos falhos numa certa medida, são recursivos, são de fato meios para o conhecimento e embora não seja possível ficar sem eles, também não é desejável a eles se submeter de forma irrestrita $[17]^{2}$

E como se dá a relação entre os modelos, teorias e realidade? Uma resposta surpreendente foi desenvolvida pelo filósofo da ciência, Mario Bunge, em sua epistemologia dos modelos [11], de onde retiramos emprestada a noção de objeto-modelo que utilizamos em nossa pesquisa. Na visão Bungeana os modelos são a verdadeira essência da atividade científica e sua construção torna-se o primeiro passo para o desenvolvimento conceitual da realidade, que se dá inicialmente por meio de simplificações e idealizações, isto é, através do que ele denomina objeto-modelo. Entretanto, os objetos-modelos são de pouca valia para a ciência se não forem engastados em

\footnotetext{
2 Como já havia alertado o físico austríaco Ludwig Eduard Boltzmann (1902) "[...] nossos pensamentos estão para as coisas na mesma relação que os modelos estão para os objetos que eles representam [...] mas sem implicar numa completa semelhança entre coisa e pensamento; pois naturalmente não sabemos quase nada sobre a semelhança entre nossas ideias e as coisas às quais nós as ligamos [...]" [16, p.2].
}

teorias gerais, de onde adquirem suas teorias específicas ou seus modelos teóricos, que estes sim podem fornecer explicações e previsões da realidade.

\subsubsection{A noção de objeto-modelo}

Os objetos-modelo são idealizações de alguma coisa ou fato real, ou supostamente real, o qual o cientista pretende investigar. Eles são concebidos por meio da observação, da intuição e da razão e quando submetidos à experiência podem apresentar tanto o seu potencial quanto seus limites, sua intenção é representar alguns aspectos da realidade observada ou imaginada. Entretanto, um objeto-modelo somente pode ser confiável para determinar algo a respeito de uma determinada realidade ou suposta realidade (coisa ou fato) se, e somente se, for construída uma teoria específica ou modelo teórico que especifique o seu comportamento. "Um objeto-modelo, mesmo engenhoso, servirá para pouca coisa, a menos que seja encaixado em um corpo de idéias no seio do qual se possam estabelecer relações dedutivas" [11, p.23]. Essa afirmação remete-nos à tese principal do filósofo da ciência em relação aos objetos-modelo: a sua real importância para a investigação científica não está na sua qualidade estética ou psicológica mas sim na sua propriedade teórica ou conceitual. Isto é, são as ideias presentes no objeto-modelo (o seu modelo teórico) mais do que sua imagem ou figuração que permitem o conhecimento de alguns aspectos da realidade.

\subsubsection{A noção de modelo teórico}

Para Bunge é o modelo teórico inserido no objeto-modelo que permite ao cientista especificar as peculiaridades da coisa ou fato investigado. Dito de outra maneira é o modelo teórico que permite ao objeto-modelo verificar se as ideias iniciais (hipóteses) levantadas sobre a realidade (coisa ou fato) são coerentes ou não passam de um simples engano. É mediante experimentações, observações e medidas, por meio de um processo lógico dedutivo, que o investigador submete à prova o seu modelo teórico e consegue então verificar quais hipóteses devem permanecer e quais devem ser abandonadas. Bunge caracteriza um modelo teórico inserido em seu objeto-modelo como um sistema hipotético-dedutivo: um conjunto de ideias em interação que permitem com que este realize explicações e previsões sobre a realidade.

Um "[...] modelo teórico é um sistema hipotéticodedutivo que concerne a um objeto-modelo, que é, por sua vez, uma representação conceitual esquemática de uma coisa ou de uma situação real ou suposta como tal. [...]" [11, p. 16]. O que precisa ser entendido a partir desse ponto é: de onde surge um modelo teórico? Há duas formas de chegar a esse entendimento, vejamos:

De acordo com Bunge em alguns casos o "modelo teórico é construído em torno do objeto-modelo. Porém em outros casos, em [...] campos mais avançados, o objetomodelo pode amiúde ser vinculado a uma teoria geral 
existente" [11, p.35]. Neste caso, são as teorias gerais (ou genéricas) que emprestam ao objeto-modelo sua base conceitual e permitem que ele (modelo) se manifeste em relação à coisa ou fato em estudo. As relações entre objetos-modelo, modelo teórico e teoria geral podem assim ser percebidas:

\begin{abstract}
"Assim, se quisermos gerar modelos teóricos do átomo de carbono, tentaremos estabelecer modelos simbólicos [objeto-modelo] dele (i.é, operadores hamiltonianos que reúnam propriedades primeiras tais como o número de elétrons e suas interações) e inseri-los na teoria geral [ou Mecânica Quântica]" [11, p. $35]$.
\end{abstract}

A segunda forma de entendimento surge quando não há uma teoria geral que possa ser confrontada com os fatos e possibilitar a manifestação de um único modelo teórico coerente com a realidade.

"Assim, na teoria da aprendizagem dificilmente há uma teoria genérica [ou geral]: cada modelo de aprendizagem [objeto-modelo] é uma esquematização de um certo tipo de experimento, e os modelos adequados nos diferentes casos parecem não adaptar-se a uma única teoria compreensiva [a um único modelo teórico]" [11, p. 35].

\subsubsection{As relações entre o objeto-modelo, o modelo teórico e as teorias gerais}

Para Mario Bunge as teorias gerais não se manifestam diretamente sobre a realidade, elas possuem um conteúdo amplo e complexo (devido em parte à sua estrutura matemática) e por isso necessitam de simplificações e idealizações que assegurem de algum modo a sua possível veracidade em relação às coisas ou aos fatos a que se referem; elas dependem dos objetos-modelo munidos de seus modelos teóricos. Na sua visão, as teorias gerais como a Mecânica Quântica, a Mecânica Celeste, a Mecânica Estatística podem emprestar parte do seu conteúdo a qualquer objeto-modelo que delas possa construir seu modelo teórico, mas sozinhas nada podem inferir em relação à realidade. A possível compreensão da realidade depende dos objetos-modelo e de seus modelos teóricos, em muitos casos, ancorados por uma ou mais teorias gerais.

Resumindo, vejamos de forma mais sintética esse processo (realidade - modelos - teorias gerais) para ver como se dá o entendimento conceitual da realidade segundo uma visão realista crítica do conhecimento científico.

De um lado temos a realidade, que diz respeito às coisas ou fatos a serem investigados pelo cientista, podendo estes ser reais ou supostamente reais. Isto é, podem ser observados ou percepcionados na natureza ou ainda apenas fruto da imaginação. Através da observação, da intuição e da razão o cientista busca uma linguagem adequada ou disponível para representar aquilo que está percebendo ou imaginando, ele então constrói um objetomodelo.

As relações entre o objeto-modelo e a realidade, num primeiro momento não passam do simples estabelecimento de semelhanças, e estas podem ser inúmeras, sendo o objeto-modelo uma idealização da realidade e uma simplificação da mesma; a representação dependerá sempre da intenção, dos objetivos e dos conhecimentos prévios do cientista, estando ela sempre atrelada aos "conhecimentos, preferências e até à paixão intelectual do construtor" $[11$, p.22].

De outro lado, temos as Teorias Gerais, que não se aplicam diretamente sobre a realidade, apesar de seu amplo conteúdo e poder de operacionalização "[...] em função de sua estrutura matemática, não se referem a nada especificamente pertencente ao mundo real, embora possam vir a se referir pela adição de suposições adicionais" [20, p. 16].

Para que o cientista consiga deduzir algo sobre alguma coisa ou fato real (ou supostamente real) em estudo, ele precisa dotar seu objeto-modelo de um corpo de ideias e então submetê-lo ao crivo da experimentação. Assim que o objeto-modelo é inserido em uma teoria geral ele "herda as peculiaridades desta e, em particular, as suas leis" [11, p.34], em consequência desenvolve seu modelo teórico, que por sua vez poderá inferir sobre a realidade. Entretanto, Bunge adverte sobre a impossibilidade de todos os modelos teóricos serem colocados à prova quanto à sua veracidade, isto é, ao serem manipulados de modo a dizerem algo de verdadeiro sobre a realidade. Por isso, o autor considera que em todos os casos as "suas consequências comprováveis se mostram aproximadamente verdadeiras" [11, p.39].

Pode-se então concluir que nem as teorias gerais e nem os objetos-modelo podem, isoladamente, dizer algo sobre a realidade. Somente quando estes se unem isso se faz possível e por meio do modelo-teórico que daí advém:

\section{"[...] a comprovação de teorias gerais demanda a produção de teorias específicas [modelos teóricos]; por si mesmas, as teorias extrema- mente gerais como a teoria da informação, a teoria geral das máquinas, a mecânica clás- sica e a mecânica quântica são incomprová- veis; o que se pode testar é uma teoria geral equipada de um objeto-modelo em suma, um modelo teórico." [11, p. 36].}

Partindo dessa colocação, adicionalmente, podemos perguntar: e se o modelo teórico presente no objetomodelo falhar, isto é, se durante as experimentações e medições, os dados empíricos por ele recolhidos não comprovarem boa parte do que nos diz a teoria geral? Bunge nos responde:

\section{"[...] ao comprovar uma teoria específica (mo-} delo teórico) em um campo avançado, nem 
sempre é claro o que se deve culpar em caso de malogro: a teoria geral, o objeto-modelo, ou ambos - mesmo na hipótese que os próprios dados sejam isentos de culpa. Em qualquer evento, sem modelo, não há prova empírica." $[11$, p. 36].

Podemos finalizar, a partir desse ponto, argumentando que os modelos (objetos-modelo e seus modelos teóricos) segundo a epistemologia Bungeana são extremamente importantes para a Ciência factual uma vez que se encontram como intermediários entre as teorias gerais e a realidade. Tudo começa com uma simplificação e idealização da realidade, constrói-se então um objeto-modelo. Depois, este é inserido em uma teoria geral (se existir) da qual ele adquire seu modelo-teórico. Como um sistema hipotético-dedutivo, "uma máquina de gerar proposições a partir das proposições iniciais" [20, p. 17], o modelo teórico, finalmente, poderá inferir sobre a realidade. É através do modelo teórico inserido no objeto-modelo que se faz possível a "ponte" entre a teoria geral e a coisa ou fato em estudo. É a partir dele que se podem gerar as explicações conceituais da realidade.

Essa visão dos modelos na Ciência é, em certa medida, também empregada por distintos pesquisadores no Ensino de Ciência, embora, em alguns casos, ela apareça apenas de forma implícita, em distintas abordagens e conceituações variadas. Pesquisas realizadas por profissionais localizados em diferentes países que por meio de trabalhos de transposição didática vêm realizando estudos teóricos e práticos, demonstrando a importância da promoção de atividades de modelagem e de modelização na escola como propulsoras de uma educação científica escolar.

\subsection{Os modelos no Ensino de Ciências na visão de alguns pesquisadores de países distintos}

A respeito do uso de modelos no Ensino de Ciências encontram-se diversos trabalhos interessantes na literatura de línguas portuguesa, espanhola e francesa [12, 20-30]. Dissertaremos a seguir a respeito de alguns desses estudos, os quais se ocupam de atividades de modelagem ou modelização, mas sem a pretensão de esgotá-los aqu ${ }^{3}$

Embora algumas vezes possam ser empregados como sinônimos, modelagem e modelização, entendidas como formas de exploração, elaboração e construção de modelos para o entendimento da realidade dos fenômenos físicos e naturais, não devem ser confundidas, são noções utilizadas em diferentes áreas. Enquanto a primeira é bem mais difundida no Ensino de Matemática, a segunda é empregada no Ensino de Ciências Naturais. A diferença parece estar nos seus objetos para representação, ou dito de outra forma, na linguagem que utilizam para representar: modelar ou modelizar os fenômenos.

\footnotetext{
3 Achamos importante, ao menos mencionar, uma bela pesquisa que resgata uma diversidade de categorias e noções de modelo presentes na literatura de língua inglesa [31].
}

Enquanto naquela geralmente vê-se o emprego dos objetos matemáticos na constituição dos modelos (modelos matemáticos), nesta, são utilizados mais como uma extensão, servindo algumas vezes como auxílio, embora, nem sempre os seus modelos sejam necessariamente matematizáveis. Eles são encontrados em alguns casos na forma de desenhos, imagens, símbolos, diagramas, objetos tridimensionais, entre outros objetos menos abstratos. Daqui para frente, daremos mais ênfase à modelização, no sentido acima exposto.

Segundo o educador em ciências, o francês Jean-Louis Martinand [23], a modelização é uma importante atividade no Ensino de Ciências e Tecnologias. É na passagem do concreto ao abstrato, do abstrato ao concreto, do teórico ao experimental, num processo de vai e vêm entre observações e teorias que se encontra o modelo como fonte mediadora de representação do conhecimento. Trata-se de uma atividade inovadora e criativa em que o modelizador se coloca a construir e adaptar os seus modelos a fim de representar a realidade observada ou imaginada, o que ele denomina "referente empírico", isto é, objetos e fenômenos ou as ações realizadas sobre estes. Em sua visão os modelos são representações hipotéticas e idealizadas dos referentes empíricos, modificáveis e condicionadas à resolução de problemas específicos, podendo ser empregados tanto para representar um fenômeno, um objeto, um evento, visando apresentá-lo em sua estrutura ou forma, quando possível, tanto quanto para explicá-lo do ponto de vista do seu funcionamento ou de suas causas.

Na escola, comenta Martinand, o importante não é o modelo em si, mas a atividade de construção e de concepção do modelo, isto é, como os alunos entendem essas representações, como eles os fabricam, quais relações estabelecem entre os modelos e as teorias, entre os modelos e as situações modelizadas e quais significados atribuem a partir daí. Assim é que "[...] a modelização pode se tornar uma [potente] ferramenta de exploração do mundo" [...] [23, p. 38].

De igual modo, essa visão sobre modelos e modelizações também é compactuada pelos didatas franceses, JeanPierre Astolfi \& Michel Develay [24] que recolhem de Martinand duas características principais desenvolvida pelos modelos na representação da "realidade natural $e$ técnica contemporânea" [24, p. 103]:

1) Facilitam a representação daquilo que está por detrás dos objetos e ou fenômenos, isto é, daquilo que está escondido e não se apresenta facilmente à observação, permitindo dessa forma, a elaboração de variáveis e de parâmetros possíveis de ser relacionáveis entre si, possibilitando o desenvolvimento de representações hipotéticas;

2) Permitem um maior número de relações entre as variáveis internas e externas aos referentes empíricos, ajudando ao modelizador a pensar na sua complexidade e a agir sobre ela.

De acordo com os didatas franceses, para a epistemologia contemporânea, "as teorias são geralmente modelizadas e o modelo corresponde apenas a uma construção 
figurada, abstrata do real" [24, p.34]. Elas são construídas, criadas, através de leis e fatos "em uma unidade coerente na maioria das vezes traduzidas por um modelo" [24]. Entretanto, entendem que não há um consenso entre " $a$ anterioridade dos fatos em relação à teoria, ou o inverso" $[24]$.

Conforme consideram, entender o caráter hipotético, sistemático e aproximativo dos modelos na apreensão da realidade é ter uma ideia sobre o funcionamento da própria Ciência. É desse modo que, a didática das ciências, ou mais especificamente o Ensino de Ciências deveria atuar em atividades de modelização, observando os limites dos modelos em sua tentativa de explicar a realidade, tendo assim a clareza sobre "o que ele permite explicar $e$ o que ele não explica". [24, p. 33] Sendo o modelo uma "representação figurada da teoria, o cientista sabe que ele é apenas uma muleta para o pensamento e em caso algum a própria realidade" [24, p. 34].

A pesquisadora argentina, Sônia Beatriz Concari [28], também compactua, em parte, das concepções dos franceses [23, 24] entendendo a modelização como uma atividade de construção de modelos que se configura na medida em que são estabelecidas relações de significado (semânticas) entre as teorias e os fenômenos, porém sem implicar numa completa semelhança entre ambos, essas relações são intercambiadas por meio de modelos que por sua vez não passam de representações incompletas e aproximadas do mundo real.

O que parece divergente entre as ideias dos pesquisadores franceses e a pesquisadora argentina, aqui referidos, reside na função atribuída aos modelos e às teorias. Enquanto para os primeiros os modelos permitem explicar algum aspecto da realidade, para a segunda os modelos são instrumentos de compreensão e conhecimento e não de explicação, a qual é uma especificidade própria das teorias. Por isso, considera importante entendermos e não confundirmos explicação com previsão e descrição. Enquanto a descrição se liga a alguma forma de definição dos fenômenos, apresentando as suas características e seus elementos constituintes, descrevendo-os de alguma forma, a explicação está relacionada à busca dos porquês dos fenômenos, ao estudo de suas causas e à testagem empírica dos enunciados da teoria. Já a previsão é uma forma de antecipar ou pressupor a ocorrência de um evento que ainda não aconteceu.

Dessa maneira, Concari [28] considera que os modelos em física não devem ser entendidos como formas de descrever ou explicar uma coisa ou evento, ela vai mais além, os modelos enquanto representações podem ser vistos como "um meio para compreender e conhecer" a realidade [28, p. 90] uma vez que, descrever e explicar cabe às teorias e não aos modelos. É pensando nesse contexto que a pesquisadora percebe como tem se manifestado o Ensino de Ciências nas escolas, baseado mais nas descrições do que nas explicações dos fenômenos, e esse papel deveria se inverter: "Nas aulas de ciência os estudantes deveriam ter oportunidades de desenvolver habilidades para proporcionar mais explicações" [28, p. 91] do que descrições e, da mesma forma, entender melhor a relação que se estabelece entre as teorias e os modelos.

Considerando a construção de modelos uma atividade fundamental na Ciência, onde sua principal função reside na capacidade de representar fenômenos, "integrados em teorias e com a capacidade de resolver problemas" [28, p. 91], a pesquisadora defende no Ensino de Ciências uma utilização de modelos que apresentem uma maior "facilidade e simplicidade" no entendimento das teorias e da realidade; modelos que permitam "uma maior significatividade potencial para o estudante" [28, p. 93].

O ponto de vista de Concari [28] nos é pertinente na medida em que coloca as teorias ou o desenvolvimento conceitual como fundamental para a produção de explicações e descrições da realidade. Uma forma de conhecer e compreender as explicações, as descrições e as previsões feitas sobre os fenômenos ocorre por meio das modelizações e de seus modelos, que por sua vez, permitem uma boa aproximação da realidade, sem na verdade atingi-la completamente.

De igual modo, o ponto de vista dos pesquisadores franceses também complementa esse entendimento, legando aos modelos a posição de intermediários entre o que se pretende modelizar: o referente empírico e as teorias. Sendo o modelo em alguns casos uma derivação própria da teoria, sua capacidade de representar a realidade é também apenas aproximativa.

Contudo, a divergência que parece haver entre a concepção dos pesquisadores franceses e da pesquisadora argentina não é tão acentuada quanto possa parecer. Pois, pode-se notar em seguida, nos argumentos de Martinand [23, p.18], uma referência à existência de algumas pesquisas estimuladas pela modelização que estudam a relação entre a "conceitualização e a modelização", e vem tentando demonstrar que: "Não há modelos sem conceitos". Assim, é possível aceitar a posição de Astolfi \& Develay [24] em relação à propriedade explicativa atribuída aos modelos. Se não há modelos sem conceitos, como indicam essas pesquisas, e se os conceitos estão bem próximos das teorias, pode-se pensar na possibilidade dos modelos também permitirem, pelo menos em parte, além da compreensão e do conhecimento, também a explicação e a previsão de alguns aspectos da realidade.

Um ponto de vista semelhante também é defendido pelos pesquisadores brasileiros, Terezinha F. Pinheiro; Maurício Pietrocola e José P. Alves-Filho [29], que consideram o conhecimento científico como um todo e o conhecimento físico em particular como uma construção teórica estruturada por modelos. É a relação entre teorias e modelos que se faz possível a representação e a interpretação da realidade. Por isso entendem que a compreensão dos papéis ou funções dos modelos é indispensável a toda atividade de ensino de física.

Ao concordarem com Drouin (1988) os pesquisadores brasileiros consideram que os modelos possuem como principal função ou finalidade "compreender, explicar, 
prever, calcular, manipular, formular" [29, p. 38] alguns aspectos da realidade ou alguns aspectos dos problemas levantados sobre ela, sendo as funções de explicação e previsão as duas mais importantes. "Explicar é uma função importante no momento de elaboração do pensamento. A explicação pode passar pela analogia ou pela análise das relações entre elementos do sistema que serve de modelo" [29, p.39]. Já prever é "antecipar o desenvolvimento de uma teoria interpretativa que constitui o fenômeno" [29, idem.]. Assim, parecem ampliar função dos modelos em relação aos autores vistos anteriormente.

Os pesquisadores brasileiros [29] consideram a modelização uma atividade essencial no âmbito do Ensino de Ciências já que ela é fruto de "um processo que consiste na elaboração de uma construção mental que pode ser manipulada e que procura compreender um real complexo" [29, idem]. Percebem que no centro dessa atividade o uso de "imagens, símbolos, esquemas, gráficos e maquetes" auxiliam na manipulação e na comunicabilidade do modelo, porém, chamam a atenção para o uso destas formas de representação que em muitos casos podem ser ambíguas.

"Uma flecha, por exemplo, pode representar fluxo de calor ou pode representar uma grandeza vetorial. A distinção entre esses significados nem sempre é evidente para os alunos e acaba se tornando uma fonte de dificuldades. Um outro problema está associado ao fato de que uma figuração é composta de aspectos que nem sempre têm significado para o modelo. Um exemplo seria a cor utilizada para representar o átomo nos desenhos que aparecem nos livros didáticos" [29, p. 40].

Embora o uso das figuras, imagens, símbolos e entre outras formas de representação sejam parte importante das atividades de modelização no ensino, elas devem receber um cuidado redobrado por parte do modelizadores que não devem sugerir que elas possam ser interpretadas como uma representação fiel da realidade, tampouco como uma construção sem história nascida na mente de um gênio e fora do mundo real. Os modelos enquanto instrumentos de trabalho dos cientistas, podem também fazer parte do trabalho de professores e de alunos, pois dizem respeito à representação de fenômenos ou de objetos que facilitam essa representação.

Por fim, os pesquisadores brasileiros consideram que geralmente o que diferencia os modelos utilizados pelos cientistas e os utilizados pelos alunos em atividades de modelização está no seu refinamento conceitual, isto é, enquanto os modelos dos cientistas permitem um grande número de relações possíveis entre os eventos estudados (com um poderio matemático considerável), os modelos dos alunos são considerados mais intuitivos, pouco matematizáveis e de fácil aceitação quando apenas uma das várias relações possíveis entre os eventos estudados é satisfeita.
Tentamos recolher até aqui, através de estudos realizados em países distintos, indícios de que atividades de modelização são bem- vindas ao ambiente escolar. Mais do que a utilização de modelos, parece pertinente a constituição de uma ideia clara dos seus usos e dos seus limites para a possível compreensão e conhecimento da realidade em estudo, com a identificação a mais clara possível do que eles permitem explicar e o que eles não explicam. Sendo o modelo uma idealização da realidade a qual pode ser alcançada de modo apenas aproximativo, a promoção da modelização no ensino forneceria uma ideia de como os cientistas realizam suas descobertas e invenções, de como relacionam as teorias e as observações, de como relacionam os conceitos e as medidas.

O ponto de vista dos autores, até aqui explorados, parece ir ao encontro da concepção dos modelos da epistemologia Bungeana [11]. Embora não usem explicitamente a noção de objeto-modelo quando falam de modelo, todos esses autores acima mencionados o colocam como o intermediário entre as teorias e a realidade, entre as teorias e os referentes empíricos, entre as teorias e as observações, além disso, entendem o seu caráter hipotético, idealizado e aproximativo da realidade, sem nunca atingi-la completamente. É essa concepção de modelo que utilizamos em nossa atividade de modelização com o grupo de 11 alunos do último ano do Ensino Médio. Será a ela que iremos recorrer para trazer a noção de "objeto-modelo mecânico concreto analógico didático" (OMMCAD), um tipo de modelo didático oriundo de um processo de transposição didática de objetos-modelo científicos.

\subsection{A noção de OMMCAD: do objeto-modelo científico ao objeto-modelo didático}

O que passamos a discutir agora é o sentido que Bunge atribui aos objetos-modelo na ciência factual: objetosmodelo do tipo conceitual ou o que designamos como objetos-modelo científicos. Retomemos uma passagem da epistemologia Bungeana dos modelos e, a partir dela, começaremos por delinear a noção de objeto-modelo mecânico concreto analógico didático que propomos nesse manuscrito.

“[...] as teorias específicas ou modelos teóricos encerram objetos-modelo do tipo conceitual mais do que representações visuais ou figurativas. Sem dúvida, é possível sempre descrever o modelo com o auxílio de um diagrama e mesmo, às vezes, com a ajuda de um modelo material - tais como os modelos esféricos de moléculas: este auxilia a compreender as idéias difíceis e algumas vezes a inventá-las. Não obstante, nem diagramas nem análogos materiais podem representar o objeto de uma maneira tão precisa e completa como o faz um conjunto de enunciados" [11, p. 25-6].

Percebe-se nesta citação que os objetos-modelo do tipo conceitual ou científico do qual fala Bunge, são aqueles 
que não necessitam de uma representação figurativa ou visual para existirem, a sua capacidade está em sua propriedade conceitual ou teorética mais do que em sua capacidade estética ou psicológica. Em seguida ele reforça esse pensamento:

"A força de um objeto-modelo do tipo conceitual não é de natureza psicológica (heurística ou pedagógica): ela reside no fato de ser uma idéia teorética e, por conseguinte, uma idéia que se pode enxertar em uma máquina teórica a fim de pô-la a funcionar e produzir idéias interessantes" [11, p.26].

A preocupação de Mário Bunge com o uso dos objetosmodelo do tipo figurativo, material ou concreto na $\mathrm{Ci}$ ência factual reside no fato de que nem sempre se pode representar a realidade através de coisas visíveis ou por meio de objetos familiares. Consequentemente, os objetosmodelo desse tipo nem sempre podem ser inseridos em teorias, já que as teorias, em seu entendimento, concebidas como "sistemas de proposições" [11, p. 27] são compostas de ideias e não de imagens.

A posição de Bunge denota a defesa de um realismo crítico e não ingênuo da realidade. Pressupõe, dessa forma, que a realidade "não é sempre, nem simplesmente, tal como parece aos nossos sentidos. O conhecimento perceptivo é deficiente 'e deve ser enriquecido pelo conhecimento conceptual, particularmente o teorético", [32, p.4]. Nesse sentido, os objetos-modelo do tipo conceitual são os que realmente importam na atividade científica.

Entretanto, apesar de não ver com bons olhos o uso de imagens ou de figurações na Ciência, uma vez que elas podem em alguns casos nos confundir e não nos deixar entender o que está para além do observável ou do perceptível, o filósofo da ciência não as ignora completamente, e percebe que em certos casos, tais formas de representação da realidade, por terem uma força de natureza psicológica mais do que lógica, quando em uso, possibilitam ao cientista a compreensão e o conhecimento de alguns aspectos da realidade. Esta suposição fora muito bem observada pelos pesquisadores brasileiros [32, p. 17-18]:

"Muitas abordagens sobre a forma como as explicações são produzidas acabam por enfatizar aspectos meramente lógicos, como afirma Bunge. Assim, a introdução dos aspectos epistemológicos, ontológico, pragmático, semântico e psicológico amplia a discussão sobre a forma como modelos teóricos podem explicar (Grifo nosso)".

É a essa possibilidade de gerar explicações psicológicas da realidade, através dos modelos teóricos presente nos objetos-modelo do tipo figurativo, material ou concreto, que os pesquisadores identificam como algo de muita valia para o Ensino de Ciências e que poderiam assim estar no centro de atividades de modelização entre professores e alunos:
"Para o ensino esta ampliação de aspectos é tanto mais importante, quando se tem em mente que, em particular, o aspecto psicológico das explicações é fundamental para os indivíduos em geral. Pois parece que ao produzirem modelos explicativos, os indivíduos buscam a compreensão daquilo que os cerca" $[32$, p.18].

E logo a seguir os pesquisadores consideram ainda:

"Cumpre notar que alguns modelos seriam mais facilmente transpostos para o contexto do ensino do que outros, em função de sua natureza. Os modelos ditos figurativos, isto é que de alguma forma se reduzem aos objetos familiares ou deles se aproximam (como as imagens de corpúsculos em movimento, por exemplo), acabam por se constituir em versões mais fáceis de serem pensadas pelos não iniciados. Para a ciência, tal característica se constitui num luxo que não deve ser perseguido. Mas em se tratando do contexto educacional, tais modelos parecem mais facilmente ensináveis (e supostamente aprendíveis)" [32, p.18].

No sentido acima exposto é que estamos propondo o uso de modelos, objetos-modelo e seus modelos teóricos, para o ensino da temática astronômica. É explorando e promovendo a capacidade psicológica de gerar explicações conceituais da realidade que os objetos-modelo do tipo conceitual (objetos-modelo científicos) são transpostos didaticamente para o ensino e tornam-se objetos-modelo do tipo concreto (objetos-modelo didáticos). Passaremos a delimitar com mais cuidado essas ideias.

\subsubsection{Do objeto-modelo científico ao objeto-modelo mecânico concreto analógico didático (OMMCAD)}

De acordo com alguns pesquisadores [13] os modelos científicos são o ponto de partida para a construção dos modelos didáticos. Devido ao seu alto grau de abstração e formalização, com seu apanhado de hipóteses e generalizações que tentam dar conta de um determinado domínio da realidade, os modelos científicos utilizados na escola são geralmente problemáticos por apresentarem uma linguagem pouco comum aos estudantes, distanciando-se em muito da linguagem e dos conhecimentos prévios que estes possuem. Dessa maneira, consideram que ensinar Ciências Naturais na escola para um grupo de estudantes requer uma reformulação dos modelos científicos em uma forma didática, de tal modo que estes não percam totalmente o seu caráter previsional e explicativo, virando uma mera simplificação [13, p. 234]. Esta transformação pela qual deve passar um determinado objeto do saber científico antes de se tornar um objeto do saber escolar foi denominada de transposição didática [14]. 
Neste momento, nossa preocupação será delinear esse caminho da transposição didática de um objeto-modelo científico para um objeto-modelo mecânico concreto analógico didático (OMMCAD), este último entendido como uma re-representação do primeiro. Pensamos assim propiciar ao leitor uma visão global do OMMCAD, oportunizando uma ideia da preparação didática pela qual os objetos do saber científico são transformados em objetos do saber escolar, tal como postula a teoria da transposição didáticą

\subsubsection{Da esfera celeste ao OMMCAD}

Se recorrermos a alguns livros científicos de astronomia não é difícil de encontrarmos algumas imagens de superfície esférica contendo um círculo máximo concêntrico a uma reta perpendicular. Em dicionários de cartografia têm-se uma melhor definição: "Esfera imaginária [...] descrita em torno de um centro [...] sobre o qual supostas posições de astros se projetam ao longo dos raios, passando pelos corpos celestes" [33, p. 101]. Estamos falando de uma das mais antigas representações já produzidas pelo homem, diga-se de passagem, pelos antigos povos gregos: a esfera celeste.

A esfera celeste, antes de se tornar uma representação pictórica ou objeto-modelo do tipo figurativo, pode ser vista como um objeto-modelo do tipo conceitual, um modelo geométrico matemático que há muito tempo tem sido utilizado em navegação e astronomia de posição para o estudo da localização dos astros no céu. É um exemplo típico do que Bunge denominou objeto-modelo do tipo conceitual ou o que aqui denominamos objeto-modelo científico. Um astrônomo ou pesquisador em astronomia sabe de antemão que a esfera celeste é uma abstração, uma ideia, um conceito, e quando ouve falar seu nome provavelmente já tenha uma representação mental para ela, sem mesmo precisar ver o seu desenho. Entretanto, para poder estabelecer relações e até mesmo ensinar a outros as ideias que estão a ela atreladas, logo necessita estabelecer uma representação pictórica (desenho), semelhante aos modelos dos livros de astronomia, enciclopédias, dicionários cartográficos e sítios da internet.

\footnotetext{
4 Trata-se aqui, especificamente, da transposição didática em sentido "stricto sensu", isto é, do trabalho de transposição [...] de um conteúdo preciso em uma versão didática desse objeto do saber [...] [14, p.46]. Esse trabalho é essencialmente uma dimensão epistemológica e metodológica da transposição didática, do qual nos valemos predominantemente. Uma outra dimensão da teoria, em sentido "lato sensu", analisa as relações do sistema educacional e suas influências (internas e externas) em torno do "saber sábio" durante o processo de sua transposição ao "saber ensinado", isto é, um trabalho mais amplo de análise sobre entrada de um objeto do saber, no saber sábio (na Ciência), e de suas transformações ao ser transposto para o saber a ensinar (saber posto nas publicações científicas e nos materiais didáticos destinados ao Ensino de Ciências) e deste, para o "saber ensinado" (saber elaborado pelo professor para ser ensinado na escola). Um trabalho de transposição didática mais amplo que ainda precisamos realizar, possivelmente num trabalho futuro, através de um curso de formação continuada para professores do Ensino de Ciências Naturais a nível de Ensino Fundamental, estendendo a temática a alunos bem mais jovens.
}

Uma representação tradicional é apresentada a seguir (Figura 1).

Essa representação é uma idealização da realidade. Ao centro da superfície esférica (esfera celeste) temos um ponto representando o planeta Terra, com seu eixo imaginário de rotação atingindo a esfera celeste em dois outros pontos opostos extremos: polo celeste norte $(\mathrm{PCN})$ e polo celeste sul (PCS). Ainda ao centro, representado por um círculo máximo, temos a projeção da linha do equador terrestre na esfera celeste: o equador celeste. Nota-se aqui que, para cada referente empírico: Terra, céu; atribuiuse, respectivamente, uma representação: ponto central, esfera celeste. Assim, conforme a epistemologia Bungeana, a relação entre a realidade e o objeto-modelo se dá inicialmente através semelhanças conceituais. No caso da esfera celeste, para cada referente empírico atribuiu-se uma representação geométrica.

Atualmente, para estudar a posição e o movimento de uma determinada estrela no céu, a partir de um ponto de vista geocêntrico (isto é, aquele ao qual se admite a Terra colocada ao centro da esfera celeste) com um suposto observador localizado em um determinado ponto de sua superfície, os astrônomos utilizam diferentes sistemas de coordenadas e suas respectivas relações matemáticas que permitem de forma muito aproximada realizar algumas explicações e previsões do comportamento dos astros. O objeto-modelo científico ou do tipo conceitual da (Figura 1), composto agora de um sistema de coordenadas horizontais, dá lugar a um novo objeto-modelo conceitual (Figura 2).

Nessa representação temos alguns conceitos semelhantes ao da (Figura 1). Por exemplo, a Terra ao centro é representada por um ponto e a esfera celeste é representada pela superfície esférica; porém agora, outros conceitos são adicionados. Por exemplo, ao centro da esfera temos o plano do horizonte de um observador hi-

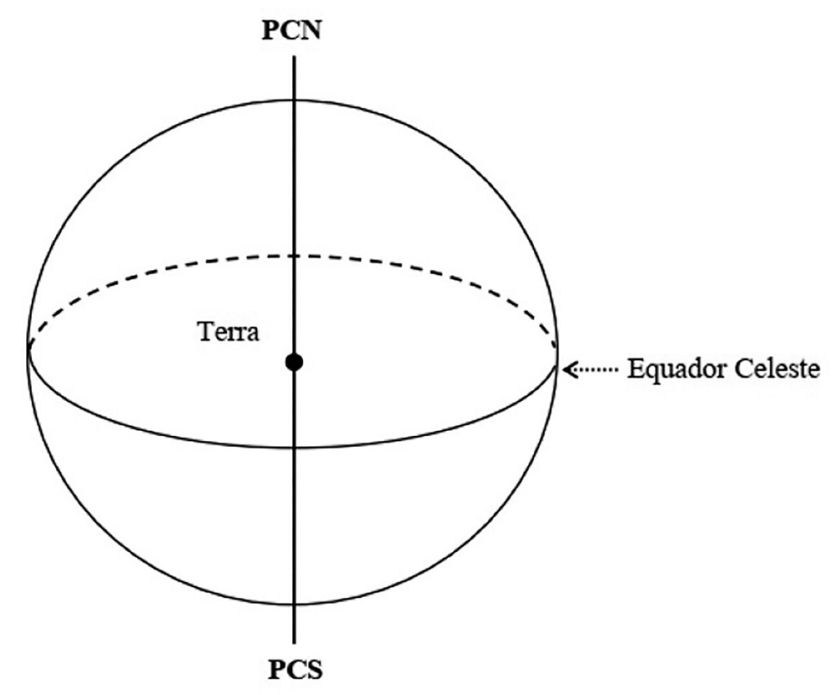

Figura 1: Objeto-modelo científico: representação da esfera celeste. 


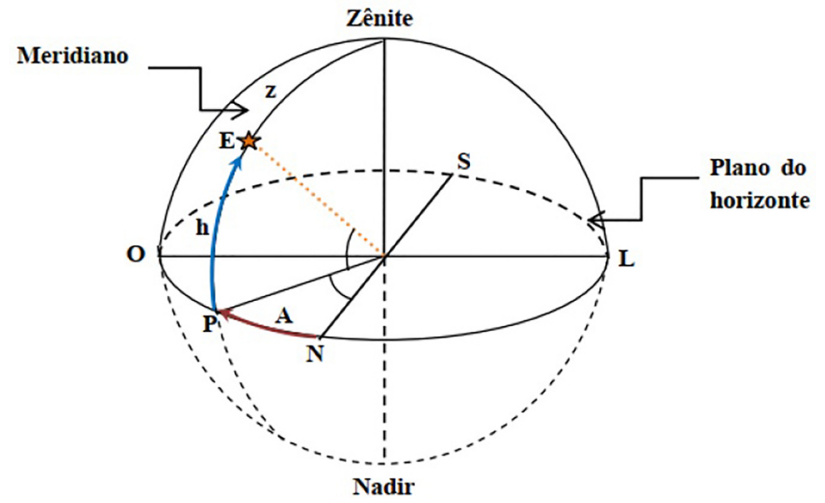

Figura 2: Objeto-modelo científico: representação do sistema de coordenadas horizontais.

potético localizado no centro da esfera celeste (sobre a superfície do planeta Terra); no plano do horizonte temos ainda a direção dos quatro pontos cardeais $(\mathrm{L}, \mathrm{O}$, $\mathrm{N}, \mathrm{S}$ ); a reta perpendicular que cruza o ponto situado no centro do disco que representa o plano do horizonte indica a direção ou o ponto diretamente acima (zênite) e abaixo (nadir) da cabeça do observador; temos também (h) = altura: indicando o afastamento angular do astro em relação ao horizonte do observador; $(\mathrm{z})=$ distância zenital: indicando o afastamento angular de um astro em relação ao zênite do observador; $(\mathrm{A})=$ Azimute, indicando o afastamento angular do semicírculo vertical do astro (arco NP) em relação ao meridiano do observador. Apresentamos aqui, a título ilustrativo, alguns conceitos importantes; outros foram omitidos.

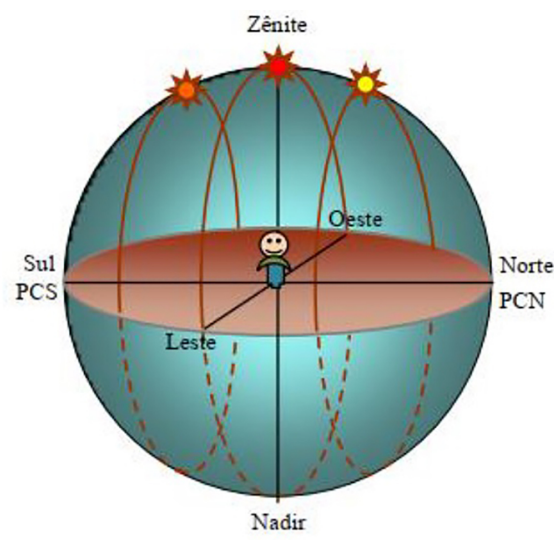

(A)
A (Figura 2) representa então o mesmo objeto-modelo da (Figura 1), porém de uma perspectiva diferente. Ficam agora mais explícitos alguns elementos da figura anterior, da forma como seriam vistos a partir de um ponto de vista de um observador na superfície da Terra, e alguns elementos da teoria matemática envolvida (geometria e trigonometria). A partir desse outro objeto-modelo conceitual seria possível derivar, por exemplo, certas previsões a respeito da posição dos astros no transcorrer do tempo.

Porém, em algumas enciclopédias de astronomia e mais particularmente em livros didáticos de geografia pode-se observar um novo objeto-modelo nascendo a partir desse último, que tem por objetivo representar o movimento anual aparente do Sol. Trata-se aqui de um caso típico de transposição do saber sábio ao saber a ensinar ou, dito de outra forma, da transposição de elementos do saber científico (astronômico) aos livros didáticos. Fica assim patente uma nova reelaboração, reformulação ou recontextualização do saber desenvolvido pelo cientista a fim de se transformar em um saber possível de ser ensinado [34]. O objeto-modelo conceitual (Figura 2) perde alguns de seus elementos e adquire outros mais intuitivos (mas mesmo assim ainda bastante abstratos), mais próximos da linguagem dos estudantes, dando origem a um novo tipo de modelo, o objeto-modelo didático (Figura 3).

Podemos perceber algumas semelhanças conceituais entre a (Figura 1), a (Figura 2) e as Figuras (3-a e 3-b): pode-se dizer que esta última é uma re-representação das duas primeiras, já que nela adicionam-se novos elementos (mais intuitivos), como por exemplo, o desenho dos sóis (fora de escala) na esfera celeste; o desenho do observador

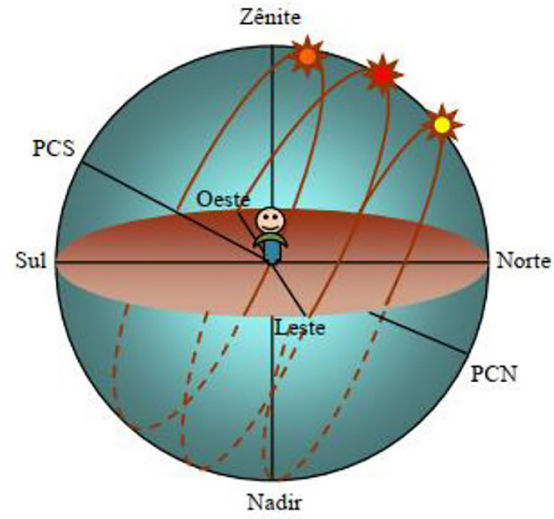

(B)

\footnotetext{
Legenda:

Sol ao meio-dia nos equinócios (HS).

* Sol ao meio-dia no Solstício de verão (HS).

* Sol ao meio-dia no Solstício de inverno (HS).
}

Figura 3: A) Objeto-modelo didático: representação do movimento anual aparente do Sol para uma latitude de $0^{\circ}$ (Macapá - AP) nas 4 estações do ano. Representação fora de escala. B) Objeto-modelo didático: representação do movimento anual aparente do Sol para uma latitude de $-30^{\circ}$ (Caxias do Sul - RS) nas 4 estações do ano. Representação fora de escala. 
hipotético (também fora de escala); as relações de medida e os ângulos que apareciam no modelo da (Figura 2) são agora retirados; adicionam-se mais cores à representação. Esses desenhos têm apenas como finalidade diminuir o número de variáveis e o grau de abstração dos referentes empíricos. Por exemplo, os sóis poderiam simplesmente ser representados por pontos geométricos; o observador ao centro não precisaria ser representado, ele aparece apenas para fornecer a ideia de que há alguém centrado na Terra observando os astros no céu. Didaticamente falando, a representação dos sóis em diferentes cores serve apenas como apoio à legenda; as pequenas chamas que saem deles são bastante usuais e de senso comum, apesar de estarem tão enraizadas em nossa cultura, demonstrando uma maneira intuitiva de perceber o formato do Sol, muitas vezes ganham reforço em fontes, símbolos e desenhos dos processadores de texto. Por isso, é preciso ter cuidado com elas, pois podem deturpar o sentido dos conceitos que estão por trás das figurações.

Assim, as características desse novo objeto-modelo podem ser consideradas mais psicológicas do que lógicas, pois sendo representadas em uma linguagem mais comum, familiar, acessível à maioria dos alunos iniciantes, procuram fornecer uma melhor compreensão dos conceitos ou ideias que seriam difíceis de ser acessadas diretamente, como seriam, por exemplo, se fossem trabalhadas imediatamente por um sistema de equações. Este objeto-modelo didático denota o que alguns pesquisadores [12] chamam de representações de ordem superior ou modelos de modelos:

"Os modelos didáticos são representações de ordem superior (modelos de modelos), obtidos por transposição a partir dos modelos científicos. Alguns mantêm os conteúdos, outros somente as formas (a arquitetura lógica) e alguns resultam da percepção dos componentes abstratos dos modelos científicos" [12, p.77].

Podemos entender então os modelos didáticos como representações dos modelos científicos. Sua elaboração envolve uma série de transformações ou transposições que afetam a forma com que os modelos científicos são estruturados, os quais passam por uma reelaboração ao nível do "plano lógico (das formas)" como também da relação entre os conceitos e os conteúdos, isto é, por uma reelaboração ao nível do "plano semântico" [12, p. 79]. Nesse sentido, trabalhar na transposição didática, ou melhor, na reelaboração de uma modelo científico para um modelo didático requer alguns critérios, tais como $[12$, p.79]:

1. Diminuir o grau de abstração;

2. Reduzir o número de variáveis;

3. Substituir o modelo atualizado por modelos aproximativos vigentes em outros momentos históricos;

4. Construir analogias que conectem o modelo a situações que sejam familiares aos alunos;
5. Utilizar metáforas que o expliquem.

Essas características dos modelos didáticos são de grande importância no contexto do ensino; no que tange especificamente ao processo da transposição didática permitem ao professor repensar a forma que dará aos seus modelos didáticos, bem como o tipo de linguagem que será a eles associada durante as atividades de modelização. Um aspecto importante a ser levado em consideração é que, apesar de possuírem pontos em comum com seus referentes científicos, os modelos didáticos enquanto modelos de modelos científicos também apresentam limitações.

Voltando ao objeto-modelo didático das (Figuras 3-a e 3-b), propomos um segundo objeto-modelo didático (Figuras 4-a e 4-b), que também possui semelhanças com o objeto-modelo conceitual das (Figuras 1 e 2), porém apresentando uma relação analógica mais potente; é o modelo geocêntrico do movimento aparente do Sol ou o que vamos definir agora como "objeto-modelo mecânico concreto analógico didático" (OMMCAD).

\subsubsection{Objeto-modelo mecânico}

O modelo é definido como "objeto-modelo mecânico" no sentido em que está inserido na mecânica clássica (teoria geral) de onde retira ou desenvolve seu modelo teórico (teoria gravitacional newtoniana); ele obedece então as leis da mecânica newtoniana. Porém, conforme Bunge $[11$, p. 37] convém lembrar que nem todos os objetosmodelo são necessariamente concretos e deterministas, eles também podem ser modelos probabilísticos.

\subsubsection{Concreto}

Utilizaremos a expressão "objeto-modelo do tipo material" ou "concreto" no sentido a ela atribuído por Galagovsky \& Aduriz-Bravo [25] quando definem os modelos ou "representações concretas" como um tipo de representações didáticas bastante utilizado no Ensino de Ciências. As representações concretas seriam "representações visuais de certas imagens associadas a algum modelo científico em particular" [25, p. 236], representações estas consideradas também científicas por estarem atreladas a conceitos científicos, mas diferentes daquelas (consideradas mais abstratas e complexas), pois possuem o papel de "simplificadores de conceitos mais complexos" [25]. Geralmente se apresentam em forma de desenhos e outras projeções como, por exemplo: "modelos moleculares feitos com palitos e bolinhas, maquetes do sistema solar, etc." [25]. Conforme o ponto de vista dos autores, os cientistas interpretam essas representações como facilitadoras para o entendimento dos conceitos científicos, entendendo as suas possíveis aplicações e limites. Porém, a "natureza mediática e metafórica" [25] dessas representações geralmente não é entendida pelos alunos como simplificações e aproximações dos conceitos científicos. Isto deve ser considerado em atividades de modelização. 


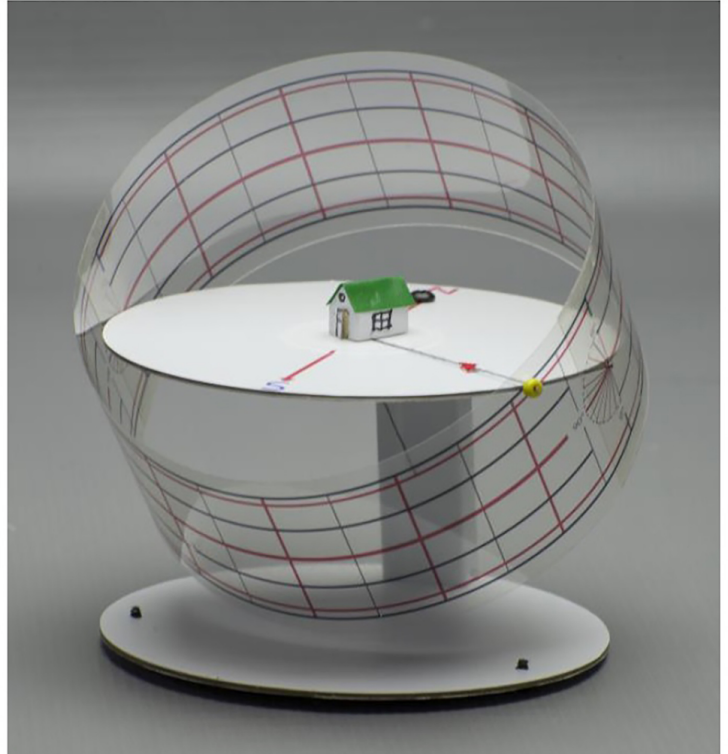

(A)

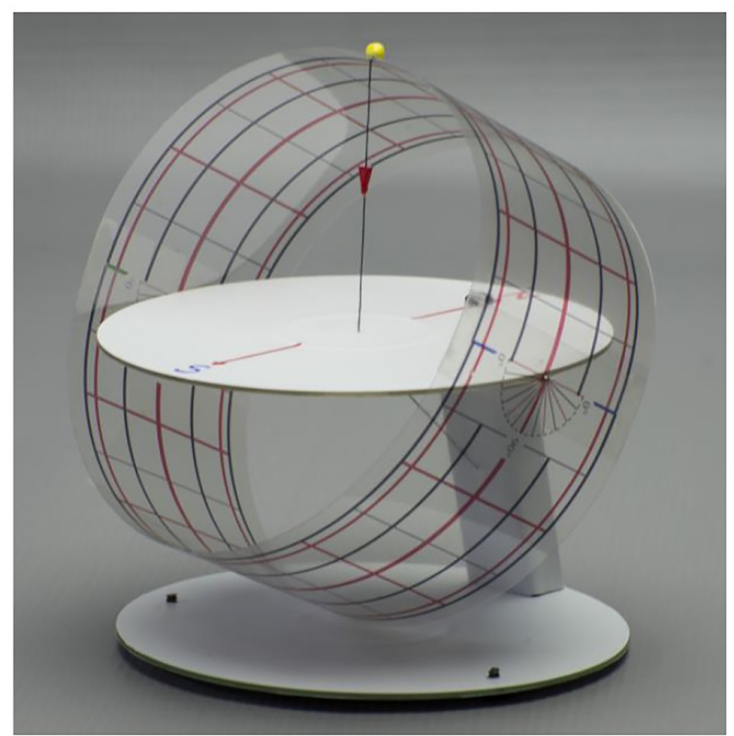

(B)

Figura 4: A) Objeto-modelo didático: fotografia do modelo geocêntrico do movimento anual aparente do Sol regulado para a cidade de Comodoro Rivadavia (Argentina) ou para uma latitude de, aproximadamente, $-45^{\circ}$ (HS). Representação fora de escala. B) Objeto-modelo didático: fotografia do modelo geocêntrico do movimento anual aparente do Sol regulado para a cidade de Curitiba (Brasil) ou para uma latitude de, aproximadamente, $23^{\circ}$ (HS). Representação fora de escala.

\subsubsection{Analógico didático}

A expressão "analógico didático" é aqui tomada em dois sentidos: "analógico" se refere às semelhanças estruturais e conceituais que o objeto-modelo didático (Figuras 4-a e 4-b) possui com relação ao seu objeto-modelo científico (Figuras 1 e 2), mas mais particularmente com o objeto-modelo da (Figuras 3-a e 3-b). Nesse sentido, ele se aproxima do que os pesquisadores denominam "aná- logo concreto" [25, p. 236]. Dito de outra maneira, o OMMCAD é um análogo concreto dos objetos-modelo das figuras anteriores. O segundo sentido para "analógico didático" se refere à forma como se trabalha com ele em atividades de modelização. Este segundo sentido guarda certa semelhança com o sentido atribuído aos "modelos didáticos analógicos" [25, p. 237], os quais marcam um avanço dos recursos didáticos análogos concretos, pois, permitiriam aos alunos utilizar-se de seus próprios meios linguísticos, da linguagem cotidiana ou comum, para realizarem suas explicações sobre a realidade, sem ignorarem é claro, a linguagem científica.

Chegamos enfim, a noção de "objeto-modelo mecânico concreto analógico didático" (OMMCAD) proposto em nossas atividades de modelização. Ele guarda certo número de relações com os modelos anteriores, especialmente com aquele posto nas (Figuras 3-a e 3-b). Uma fotografia do OMMCAD, regulado para duas cidades de países distintos, uma no Brasil e outra na Argentina, é vista a seguir.

O OMMCAD pode ser visualizado em seus detalhes nas fotos das figuras ao lado; para a sua construção utilizamos dois CDs; um deles forma a base e o outro "materializa" o plano do horizonte do observador. Os CDs são sustentados por um suporte de madeira; um cilindro feito a partir de uma figura impressa em uma lâmina de transparência representa a esfera celeste na qual os círculos representam a região da esfera celeste onde o Sol realiza seu movimento anual aparente, tudo em relação a um observador localizado em qualquer uma das diferentes regiões do planeta Terra. A passagem do Sol abaixo e acima do plano do horizonte, indicando o período em que a Terra não recebe luz solar (noite) e o período em que recebe luz solar (dia claro), é mensurada por um escala horária dividida em 24 partes (24 horas).

Com o OMMCAD é possível prevermos, de modo bastante aproximado, o intervalo de tempo em que o Sol permanece acima do horizonte (período de luz solar) em qualquer época do ano e em qualquer região da Terra; bem como abaixo dele (período sem luz solar); também é possível identificarmos as diferentes posições do nascimento do Sol, em relação ao plano do horizonte, ao longo do ano - mostrando assim os dois únicos dias do ano em que o Sol tem seu nascimento exatamente no ponto cardeal Leste e ocaso no ponto cardeal Oeste (os chamados equinócios de primavera e outono), além da posição do Sol nos Solstícios. Muitas outras relações podem ser materializadas; o OMMCAD não se restringe à possibilidade de efetuar previsões, ele pode constituir-se num excelente recurso para o estudo, em especial pelo fato de ser "regido" por importantes conceitos matemáticos e físico-astronômicos.

Se voltarmos às Figuras (3-a e 3-b) logo podemos notar algumas relações de semelhança entre elas e o OMMCAD, aqui ilustrado em detalhes nas Figuras (4-a e 4-b). O plano do horizonte do observador e a esfera celeste com seus círculos indicadores do movimento anual aparente do 
Sol (em 3-a e 3-b) passam agora a ser representados (em 4-a e 4-b), respectivamente, por um CD e uma lâmina de transparência, com círculos nela impressos. Com a diferença que em (4-a) temos a representação do movimento aparente do Sol para a região de Comodoro Rivadavia na Argentina (latitude de $-45^{\circ}$ ) e em (4-b) para a região de Curitiba (latitude de $-23^{\circ}$ ), como se pode perceber também nas Figuras (3-a e 3-b), para as latitudes de Macapá $\left(0^{\circ}\right)$ e Caxias do Sul $\left(-30^{\circ}\right)$, respectivamente.

O OMMCAD passa a ser então um "análogo concreto" daquele (Figuras 3-a e 3-b). Ele se vale em sua construção, tanto de relações analógicas estruturais ou substanciais, quanto de relações analógicas formais ou funcionais, isto é, existe uma relação de semelhança ao nível da estrutura, das formas, quanto uma relação de semelhança ao nível do funcional, das funções, com o objeto-modelo das Figuras (3-a e 3-b). A relação de semelhança estrutural não é perfeita, pois, a faixa de transparência em primeiro lugar é cilíndrica e não esférica, em segundo lugar, representa apenas a região da esfera celeste em que o Sol aparentemente se movimenta e não toda a região do "céu". Mas não há nenhum problema do ponto de vista da analogia funcional, já que tanto a faixa de transparência quanto a representação esférica, ambas representando a esfera celeste (isto é, representando uma ideia e não uma coisa real) apresentam a direção do céu em que o Sol aparentemente se movimenta em relação a um observador hipotético. Dito de outra forma, ambos os modelos possuem a mesma função, representar o movimento anual aparente do Sol a partir de um ponto de vista geocêntrico.

Apesar do que foi notado acima, pode-se dizer que o OMMCAD é mais significativo que o seu modelo precursor, àquele das Figuras (3-a e 3-b), e tem um poder de operacionalização muito maior. De um lado, o OMMCAD apesar de ser um análogo concreto daquele, é mais intuitivo, tem o poder de "materializar" alguns conceitos abstratos, permitindo aos seus modelizadores (professores e alunos), por exemplo, alterar de várias maneiras a posição da "faixa" (do movimento anual aparente do Sol) posicionando-a em qualquer região do planeta, realizando assim centenas de previsões (o que é de fato impossível com o modelo que lhe deu origem (Figuras 3-a e 3-b) a não ser que seja lançada mão de novos modelos). De outro lado, ele possibilita um ganho na perspectiva geométrica, pois propicia a passagem de um modelo anteriormente estático (ao nível do papel) para um modelo agora semidinâmico (ao nível do perceptível, do manipulável e do modificável).

Tentamos apresentar, por meio do subtítulo: "Da esfera celeste ao OMMCAD", um exemplo de como pode se dar a transposição de um objeto do saber científico em um objeto de ensino. Mostramos também as necessárias reelaborações e reconstruções pelas quais um determinado objeto-modelo científico passa antes de se transformar em um objeto-modelo didático, que por sua vez, é entendido como uma re-representação daquele, agora numa nova estrutura e com uma linguagem mais próxima da utilizada pelos alunos iniciantes.

\section{As atividades desenvolvidas e alguns resultados encontrados}

O método de ensino que empregamos com nosso grupo de 11 alunos do último ano do Ensino Médio, antes de iniciarmos com a modelização e exploração do OMMCAD propriamente dita, baseou-se na exploração de uma pluralidade de objetos-modelo didáticos em distintos ambientes de aprendizagem [10, p.83]. Iniciamos na sala de aula da escola, através do estudo de um texto do saber, com o debate em torno das noções de esfera celeste e de plano do horizonte, a fim de facilitar o acesso a uma parte do modelo teórico do OMMCAD [10, p. 134]; depois fomos ao laboratório de física para a simulação do modelo Sol-Terra a fim de desmistificar a ideia de senso comum bastante difundida entre os alunos de que a principal causa das estações do ano está numa maior (inverno) ou menor (verão) aproximação entre o Sol e a Terra [10, p.144]; depois mais fomos ao planetário inflável do museu de ciência da UCS onde trabalhamos no estudo do movimento aparente do Sol e no estudo das diferentes posições do seu nascimento ao longo do ano [10, p.153]. Essas foram algumas das atividades de modelização que percebemos necessárias para um melhor entendimento da temática astronômica e de parte do modelo teórico presente no OMMCAD, o qual por fim passou a ser, coletivamente, objeto de nossa construção. Contudo, é importante frisarmos que nesse manuscrito não temos a intenção de descrever essas atividades de forma minuciosa, pois suas interações são inúmeras e extrapolariam os limites deste texto. Tentaremos seguir o nosso objetivo de divulgar alguns resultados encontrados, com nosso grupo de alunos, após a elaboração e exploração do OMMCAD segundo suas consequências mais relevantes.

A pesquisa envolveu, inicialmente, antes de qualquer atividade prática, a aplicação de um questionário de perguntas abertas [35] que nos permitiu recolher as concepções prévias dos alunos em torno da temática. Ao final das atividades de modelização aplicamos uma entrevista semiestruturada [36] a fim de identificar o que ficou e o que mudou para os alunos em termos de conhecimento. As entrevistas foram realizadas de modo individual, gravadas em áudio e vídeo, com duração média de 10 minutos cada uma, onde cada participante respondeu a algumas perguntas em torno da temática, com a opção de recorrer ao OMMCAD caso achasse necessário. O método para interpretação dos dados que foram recolhidos (no questionário e nas entrevistas) foi $o$ da análise textual discursiva [37]. Utilizamos uma tabela [10, p.206-7], gerada pelo Observatório Naval Americano (USNO), contendo dados para a duração aproximada do "dia claro" para Caxias do Sul, Macapá e Polo Sul, em comparação com os dados que eram medidos, retirados da faixa graduada do OMMCAD. 


\subsection{Em relação às diferentes direções do nascimento do Sol ao longo do ano}

Conforme verificamos nos questionários, e depois confirmamos na sessão do planetário inflável, a totalidade dos alunos havia aprendido na escola que o "Leste" e o "Oeste" eram as únicas direções do nascimento e do pôr do Sol ao longo do ano. Não tinham conhecimento de que esse fenômeno ocorria apenas em dois dias do ano, nos equinócios de primavera e outono. Apenas um aluno (Pet), como veremos em seguida, mesmo tendo recebido anteriormente este conceito de forma equivocada na escola, sabia (graças talvez ao seu senso comum) que o Sol nascia em diferentes posições ao longo do ano, mesmo sem saber a causa.

De modo geral, as concepções dos alunos eram provavelmente as mesmas de seus antigos professores, ideias possivelmente ligadas aos erros conceituais ainda presentes nas representações dos livros didáticos [4]. Após a realização das atividades nos diferentes ambientes de aprendizagem, principalmente com o planetário inflável e com o OMMCAD, apareceram fortes indícios de que houve a superação da maioria das concepções errôneas que boa parte dos alunos apresentava, conforme os discursos que apareceram.

(Rob), que tinha respondido explicitamente no questionário que o Sol nascia sempre no Leste, agora na entrevista muda de opinião e com o OMMCAD em mãos apresenta o seu novo ponto de vista:

"Além das três questões feitas originalmente: há alguma dúvida ou questão que você não conseguia dar conta, e que agora você consegue responder sobre este assunto? Qual?" (pesquisador).

"Seria isso que... (levando as mãos ao OMMCAD) Dependendo da estação do ano... Do posicionamento da Terra... Ele [o Sol] pode nascer mais cedo ou mais tarde...Isso aqui... (com o OMMCAD em mãos) mudou totalmente o meu conceito. Eu botei [no questionário] que o Sol nascia sempre ao Leste como eu aprendi na terceira ou quarta série através daquele desenhinho de como se orientar: o Sol nasce sempre ao leste então estica o braço direito ao leste, então a frente é o norte, as costas o sul e a esquerda o oeste... (sempre fazendo gestos com os braços, apontando para as diferentes direções). Isso eu tinha como fixo... Tipo... Então o Sol ia nascer sempre ali [no Leste] então. Tinha fixo pra mim e agora isso mudou... Tipo... Lá no planetário também deu para perceber isso." (Rob).

Nos comentários de (Rob) podemos perceber que o OMMCAD e o planetário inflável foram fundamentais para a compreensão de que o Sol não nasce sempre exatamente na direção Leste; concepção esta que ele havia adquirido na escola através de um "desenhinho" que provavelmente fora retirado de um livro didático.

(Kel) que nas respostas iniciais (questionário) parecia ter um bom entendimento sobre o fenômeno, não mencionando explicitamente a sua crença sobre o Sol nascer ou não no Leste, agora, em resposta a outra pergunta da entrevista deixa explícito o que havia aprendido na escola e o que mudou depois de ter participado das atividades.

"O que você teria a dizer sobre o nascimento do Sol durante o ano? Você chegou a aprender algo novo?" (pesquisador).

"Com certeza! Que ele não nasce só no Leste como a gente tinha aprendido na escola, que conforme a movimentação e as estações e tal ele muda de lugar, ele nasce mais para um lado mais para o outro e que na verdade o Sol só nasce no Leste dois dias por ano! Completamente fora do que a gente tinha aprendido na escola, mas foi bem bom saber. Alías foi ruim saber que a gente estava errado né! A gente sempre pensou errado, mas foi bom descobrir o jeito certo de pensar." (Kel).

Apenas (Pet) já sabia de antemão que o Sol não nascia sempre no leste, apesar de seus professores terem lhe ensinado o contrário, seu conhecimento sobre as diferentes direções do nascimento do Sol provinha apenas das suas observações realizadas no cotidiano.

"O que você teria a dizer sobre o nascimento do Sol durante o ano? Você chegou a aprender algo novo?" (pesquisador).

"Pelo que eu sabia o Sol não nasce né!... (sorrindo muito) A nossa visão dele assim oh!... Acontece... A gente consegue ver conforme o plano do horizonte!... É plano do horizonte né? Então conforme ele passa pelo plano do horizonte... (ao argumentar o aluno manipulava o OMMCAD) Então a nossa visão, conforme o planeta vai girando então ele [o Sol] aparece...Em épocas a gente consegue ver ele por mais tempo... Em épocas por menos tempo...Em lugares da Terra tu vai ver ele mais alto [no céu],[ em outros] mais baixo." (Pet).

"E em relação à posição tu terias algo a dizer?" (pesquisador).

"A posição ela vai variando né, conforme o ângulo... Tipo... Por exemplo...(manipulava o OMMCAD)... Ela vai do Norte... Vai indo até o... Um pouco pro Leste... Começa no Leste... Vai um pouco pro Sul... Volta pro Leste... Tem essa movimentação durante o ano." (Pet). 
"Você já sabia dessa variação da posição do nascimento do Sol durante o ano?" (pesquisador).

"Eu sabia que tinha uma variação, mas não sabia como? qual que era essa variação? como é que funcionava? para que lado que ia? o por quê? Pois eu sabia que o Sol nem sempre nascia no Leste, apesar dos professores terem me ensinado onde ele nascia eu já tinha observado que às vezes aparece mais forte na janela, outras vezes aparece menos, algumas vezes mais pro canto [da janela]." (Pet).

"Olha só que interessante! E você nunca contestou teus professores?" (pesquisador).

"Não! Éh!... Eu nunca tinha parado para observar que eles tinham me ensinado que o Sol nascia sempre no Leste." (Pet).

Nos argumentos de (Pet) podemos perceber um domínio conceitual mais apurado que o utilizado pelos demais alunos, o que pode ser constatado pela utilização constante do OMMCAD como recurso para expor seus argumentos e gerar as explicações da realidade; ele parece assim ter se apropriado das noções de plano do horizonte e de variação da direção do nascimento do Sol ao longo do ano com bastante propriedade.

Verificamos assim que os alunos, de modo geral, demonstraram ter modificado as suas concepções prévias em relação à direção do nascimento do Sol. Muitos deles, ou utilizaram o OMMCAD ou mencionaram o planetário inflável para demonstrar o seu "novo" conhecimento adquirido, ou seja, que o Sol não nasce apenas no Leste como teriam aprendido na escola. Ele muda de lugar, dia após dia, lenta e gradualmente, conforme é possível intuitivamente retirar do OMMCAD 5

\subsection{Em relação à duração aproximada do "dia claro"}

Numa das perguntas do questionário procuramos identificar as concepções prévias dos alunos no que diz respeito à variação do período de luz solar ao longo do ano, da duração aproximada do "dia claro". Foi quando percebemos que dos dez alunos que responderam a pergunta, quatro deles acreditavam que a duração do "dia claro" não mudava, ela continuava sempre a mesma.

Depois de trabalharmos essa questão com o planetário inflável e de forma mais precisa com o OMMCAD, percebemos que os alunos, de modo geral, demonstraram ter adquirido um bom conhecimento a esse respeito, pois um

\footnotetext{
5 Em um artigo anterior, denominado "Um modelo para o movimento aparente do Sol a partir de uma perspectiva geocêntrica" [38], havíamos descrito os detalhes para a elaboração e construção do OMMCAD, o qual naquela época não tinha essa fundamentação. Nele disponibilizamos uma tabela [38, p. 19] com valores aproximados para a declinação Solar.
}

bom número se mostrou participativo e convincente em seus argumentos e previsões. Mesmo assim, procuramos nos certificar. Tentamos identificar numa das perguntas da entrevista em que medida as concepções prévias desses alunos haviam evoluído, se eles recorreriam ou não ao OMMCAD para gerar suas explicações e previsões da realidade? Desse modo, com uma pergunta mais específica, procuramos identificar se eles conseguiam prever em qual época do ano em Caxias do Sul (RS) a duração aproximada do "dia claro" era maior, isto é, em qual época do ano, em Caxias do Sul, o Sol fica a maior parte do tempo acima do plano do horizonte?

Verificamos então, que dos alunos que responderam a entrevista (onze ao total), apenas um deles não conseguiu responder a pergunta e tampouco operar com o OMMCAD. Dos dez alunos que conseguiram respondê-la, sete manipularam o modelo para gerar as explicações e previsões, enquanto que outros três apenas olhavam para ele como se buscassem consultá-lo. Vejamos alguns casos.

Os casos de Rob, Ted, Mel e Pet ilustram muito bem a tendência do uso ou do recurso ao OMMCAD para responder à pergunta; todos percebem que no verão o Sol fica por mais tempo acima do plano do horizonte.

"Você saberia dizer em que época do ano, em sua região, o Sol fica a maior parte do tempo acima do plano do horizonte?" (pesquisador).

"Seria o verão... Tem maior duração. (apontando com o dedo para o arco de circunferência indicativo da entrada do verão)" (Rob).

"Acho que é no verão. Porque tem mais tempo de luz solar durante o dia (apenas olhava para o OMMCAD)... Porque os dias acabam se tornando mais longos." (Ted).

"Acima do plano? (começou a manipular o OMMCAD) Verão! Por que tem... 14 horas quase de Sol... (apontando com o dedo para o arco de circunferência indicativo da entrada do verão). Com o modelo é bem melhor de ver isso, por que tipo... Tem as escalinhas." (Mel).

"No verão! Tipo... Com o modelo (apontou com a mão para o OMMCAD) é super óbvio!... Não tem nem como contestar." (Pet).

Já no caso de (Fra), podemos observar o não entendimento do fenômeno; diferentemente dos outros colegas ela não faz uso do modelo para gerar a sua explicação e previsão da realidade; mesmo quando o pesquisador aventa o uso do modelo a aluna apresenta dificuldades.

"Você saberia dizer em que época do ano, em sua região, o Sol fica a maior parte do tempo acima do plano do horizonte?" (pesquisador).

"Eu... Eu não saberia." (Fra). 
"E como o modelo você conseguiria?" (pesquisador).

"Éh! Acho que sim. Deixa eu ver... (apenas nesse momento a aluna pegou o OMMCAD em mãos para então responder:) Aqui no meio...(apontando com o dedo para o arco de circunferência indicativo dos equinócios)" (Fra).

\section{Conclusão}

Primeiramente precisamos agradecer aos leitores pela paciência em nos acompanhar até aqui. Reconhecemos que esse texto se tornou talvez demasiadamente longo (e humildemente pedimos desculpas), mas preferimos deixálo assim a correr o risco de omitir partes importantes. Nossa tentativa foi a de iluminar o cenário em torno da noção de modelo na Ciência e no Ensino de Ciências, a fim de apresentar a noção de OMMCAD que propomos para o ensino da temática astronômica do a) movimento aparente do Sol, b) das diferentes posições do nascimento do Sol ao longo do ano e c) da duração aproximada do "dia claro" para qualquer região da Terra.

Resgatamos de forma muito breve o debate em torno do conceito de modelo na Ciência, anunciando a sua primeira aparição na investigação científica através dos modelos mecânicos e das analogias em física (1860), depois apareceram os modelos da lógica matemática (1920), depois mais em meados de (1950) os modelos matemáticos, os objetos-modelos e seus modelos teóricos e, depois mais ainda, numa concepção mais contemporânea, os programas computacionais (1980). Trabalhamos esse assunto de forma mais detalhada num outro manuscrito [16], e aqui sucintamente argumentamos que atualmente não é possível propor uma definição universal do que é um modelo. Um desenho, um diagrama, um esboço, uma ilustração, um objeto concreto (OMMCAD), uma estrutura matemática (modelo simbólico), um software de computador, uma cópia de alguma coisa (modelo icônico), tudo isso pode ser considerado modelo de algo. Tomados no sentido epistemológico todos podem ser considerados como estruturas concretas ou abstratas que visam de alguma forma representar alguns aspectos de uma determinada realidade - fato ou coisa [11], fenômeno [18]. Assim, na investigação científica, parece que mais importante do que encontrar uma única e precisa definição para o conceito de modelo é a identificação das suas funcionalidades 6 .

Chamamos a atenção para o papel dos modelos na Ciência enquanto objetos de representação da realidade. De um objeto meio abstrato, meio concreto sempre com

\footnotetext{
6 Convidamos o leitor à leitura do manuscrito intitulado "os modelos na ciência: traços da evolução histórico epistemológica" [16], onde é possível ter uma melhor compreensão, de forma mais abrangente que a aqui exposta, sobre o cenário em torno das distintas noções de modelo na ciência, desde sua inserção no debate científico até os dias atuais.
}

a função de auxiliar as teorias no processo da descoberta ou da invenção da realidade; ao modelo cabe então, em muitos casos, a realização da testagem empírica das teorias, em outros casos, a construção de novas teorias. Para a Ciência, o modelo tornou-se quase que um "mal necessário", pois, mesmo impreciso e com limitações, sem modelo a realidade fica muito mais complexa e inacessível. Nesse sentido, acreditamos que o conhecimento da noção de modelo científico torna-se de fato fundamental para o Ensino de Ciências, uma vez que no processo da transposição didática são os modelos científicos que emprestam seus fundamentos aos modelos didáticos, os quais passam a carregar uma nova estrutura, uma nova linguagem, menos lógico-matemática e mais psicológico-figurativa, mais próxima da linguagem utilizada pelos alunos iniciantes. Assim, precisamos ter em mente que, do mesmo modo que nos modelos científicos, nos modelos didáticos há sempre um bocado de limitações e, não é demais desconfiar das imagens (pois elas encontram-se carregadas de conceitos, de ideias que, com alguma frequência, podem fornecer falsas, ou enganosas, correlações com a realidade).

Tomamos como referência a epistemologia Bungeana dos modelos e algumas considerações da didática das ciências para conceituar a noção de objeto-modelo mecânico concreto analógico didático (OMMCAD) empregado em nossa pesquisa. Tentamos demonstrar que os objetosmodelo didáticos, em geral, são representações conceituais figurativas, materiais ou concretas de objetos-modelo científico, obtidas por meio de processos de transposição didática, que auxiliam os alunos não apenas na construção de explicações psicológicas da realidade como também no levantamento de algumas previsões sobre ela. Como vimos no caso de (Pet), ao dizer que a estação de maior duração aproximada do dia em Caxias do Sul (RS) era o "Verão" e que "com o modelo é super óbvio... Não tem nem como contestar (Pet)". Assim como o caso de (Mel), que conseguiu prever com o modelo que a duração aproximada do dia nessa estação tem "14 horas quase de Sol. Com o modelo é bem melhor de ver isso, porque tipo...tem as escalinhas $(\mathrm{Mel})$ "; de fato uma previsão que pode ser realizada com o modelo, entre incontáveis previsões que podem ser dele emanadas, basta ao aluno regulá-lo para a latitude escolhida e realizar a medição na faixa graduada.

Trouxemos ainda algumas considerações de educadores em ciência sobre as suas concepções a respeito da noção de modelo; pesquisadores localizados em países distintos (França, Argentina, Brasil) que trabalham com atividades de modelização. Percebemos nesses estudos uma visão de modelo bastante próxima da epistemologia Bungeana dos modelos, uma vez que todos os autores estudados consideram o modelo como "pontes" de ligação entre as teorias e a realidade, entre as teorias e os referentes empíricos, entre as teorias e as observações, além de entenderem a sua característica hipotética, idealizada e aproximativa da realidade, sem nunca atingi-la completamente. Apesar dessa proximidade, parece não haver um 
consenso entre eles com relação às funções atribuída aos modelos e as teorias. Para alguns, os modelos são objetos que levam ao conhecimento e a compreensão da realidade, mas não permitem a sua explicação, já que esse é um papel atribuído às teorias [28]. Para outros, os modelos não só auxiliam na compreensão e no conhecimento da realidade como também permitem, ao menos em parte, a construção de explicações e previsões sobre ela, já que entendem que não existem modelos destituídos de conceitos [24]. Outros ainda atribuem essas e outras funções, como as de calcular, manipular e formular alguns de seus aspectos [29].

A pesquisa com os alunos de Ensino Médio nos permitiu descobrir que o OMMCAD foi de fato um objeto do saber a ensinar adequado para trabalharmos com a temática do movimento aparente do Sol, oportunizando aos alunos, através da exploração do conteúdo psicológico ${ }^{7}$ do modelo, uma compreensão mais intuitiva do conceito de declinação solar, por exemplo; ou melhor, oportunizou lhes o entendimento de que o Sol não nasce "sempre" no Leste e se põe "sempre" no Oeste, conforme aprenderam na escola com seus antigos professores (baseados nas representações inadequada dos livros didáticos). Assim como afirmou (Kel) quando perguntado se havia aprendido algo novo: "Com certeza! Que ele não nasce só no leste como a gente tinha aprendido na escola" ou como afirmou (Rob): "Eu botei [no questionário] que o Sol nascia sempre ao leste como eu aprendi na terceira ou quarta série através daquele desenhinho de como se orientar". Esse era um conhecimento que era, para eles, dado como certo, e que agora sofreu uma reformulação: "Então $\boldsymbol{o} \boldsymbol{S o l}$ ia nascer sempre ali [no Leste] então. Tinha fixo pra mim e agora isso mudou" (Rob). Houve uma mudança de concepção em praticamente todos os alunos, o Sol nasce no Leste sim, mas "apenas em dois momentos", como manifestou muito bem (Kel): "que conforme a movimentação e as estações e tal ele muda de lugar, ele nasce mais para um lado mais para o outro e que na verdade o Sol só nasce no leste dois dias por ano!" (Kel).

É importante frisar sobre as limitações do OMMCAD. Embora as suas previsões sejam muito próximas da realidade, oportunizando aos modelizadores descobrir a duração do "dia claro" para qualquer região da Terra, de modo bastante aproximado (basta para isso comparar com a medida gerada por uma tabela no computador, a diferença é muito pequena), ele não pode ser considerado

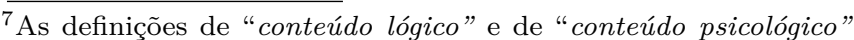
de uma teoria foi proposta pela primeira vez em (1956) pelos precursores da inteligência artificial, Herbert A. Simon e Allen Newell [39] em um dos seus artigos, dedicado aos modelos. Os cientistas consideram por conteúdo lógico "aos fatos que podem ser extraídos dela [da teoria] através da aplicação das leis da lógica". E por conteúdo psicológico, "as proposições empíricas que o cientista é de fato capaz de derivar dela" [39, p. 68-9]. Ambos os conteúdos são de grande valor para o cientista, porém o conteúdo psicológico é o que pode lhe dar acesso às afirmações da teoria em relação aos fatos.
}

como um relógio. Para isso, o modelo precisaria ser aperfeiçoado através da consideração de que a órbita da Terra não é perfeitamente circular (apesar de estar muito próxima disto); a elipse descrita (com o Sol num dos focos) implica numa velocidade orbital da Terra em torno do Sol, variável, e a intensidade dessa variação depende da época do ano. Ocorre assim uma alteração (cumulativa) na duração do dia solar; a questão do relógio pode então ser respondida a partir daí.

Acreditamos que o trabalho de modelização com objetosmodelo didáticos em nosso estudo, especialmente no caso do OMMCAD, poderá contribuir com a superação de um dos principais desafios para o Ensino de Ciências na atualidade: a necessária "superação das insuficiências do livro didático", conforme vêm chamando a atenção renomados pesquisadores [15]; material que apesar de vir sendo objeto de avaliação desde 1994 pelo Programa Nacional do Livro Didático (PNLD) ainda assim continua apresentando problemas conceituais e de representação em seu conteúdo, em muitos casos, devido a sua construção e desenvolvimento não passar pela análise crítica dos pesquisadores da área. Segundo apontam ainda os educadores em ciências: a superação do livro didático poderá ocorrer na medida em que os professores deixarem de ficar reféns do seu conteúdo e passarem a pesquisar em outros materiais didáticos e a utilizar outros espaços educacionais; artigos de revistas especializadas, modelos didáticos, museus, planetários, clubes de ciências, são algumas possibilidades que podem melhorar tanto o ensino quanto a aprendizagem.

Em um trabalho futuro pretendemos desenvolver um curso de formação continuada para professores do Ensino de Ciências Naturais, ao nível do Ensino Fundamental, oportunizando aos professores uma reflexão em torno das noções de modelo na Ciência e no Ensino de Ciências, preparando-os para futuramente aplicarem com seus alunos a metodologia da modelização empregada em nossa pesquisa, com as devidas adaptações; Ou seja, pretendemos identificar se o método de modelização que empregamos com os alunos do último ano do Ensino Médio (mais velhos) é também adequado para ser trabalhado com alunos (mais novos) dos Anos Finais do Ensino Fundamental? Com certeza mais um grandioso e belo desafio, em nossa tentativa de popularização do OMMCAD entre professores e alunos de nível Fundamental, onde a temática astronômica é proposta pelos documentos oficiais, mas é carente de materiais didáticos contemporâneos, aparecendo ainda de forma muito tímida. Vamos modelizar?

\section{Agradecimento}

Os autores agradecem aos revisores da RBEF pelas valiosas sugestões oferecidas. 


\section{Referências}

[1] A. Villani, Revista Brasileira de Ensino de Física 11, 130 (1989).

[2] J.M. Barrabín, Enseñanza de las ciências 13, 227 (1995).

[3] C. Franco, Ciência \& Ensino 4, 10 (1998).

[4] S.M. Bisch, Astronomia no $1^{\circ}$ grau: Natureza e Conteúdo do Conhecimento de Estudantes e Professores. Tese de Doutorado, Universidade de São Paulo, São Paulo (1998).

[5] C. Leite, Os Professores de Ciências e suas Formas de Pensar a Astronomia. Dissertação de Mestrado, Universidade de São Paulo, São Paulo (2002).

[6] S.R. Teodoro, A História da Ciência e as Concepções Alternativas como Subsídios para o Planejamento de um Curso sobre Atração Gravitacional. Dissertação de Mestrado, Universidade Estadual Paulista, São Paulo (2000).

[7] E.J.M. Lima, R.H. Trevisan e J.B. Cleiton, in Anais do XVI Simpósio Nacional de Ensino de Física (Sociedade Brasileira de Física, Rio de janeiro, 2005).

[8] A.L. Scarinci e J.L.A. Pacca, Revista Brasileira de Ensino de Física 28, 89 (2006).

[9] R. Langui e R. Nardi, Caderno Brasileiro de Ensino de Física 24, 87 (2007).

[10] F.S. Silva, Objetos-modelo no ensino de astronomia e o processo da transposição didática. Dissertação de Mestrado, Universidade de Caxias do Sul, Caxias do Sul (2011).

[11] M. Bunge, Teoria e Realidade (Editora Perspectiva, São Paulo, 1974).

[12] A. Adúriz-Bravo e L. Morales, Caderno Catarinense de Ensino de Física 19, 76 (2002).

[13] L. Galagovsky e A. Adúriz-Bravo, Enseñanza de las ciências 19, 231 (2001).

[14] Y.Chevallard, La Transposición Didática: Del Saber Sábio Al Saber Enseñado (Aique grupo Editor, Buenos Aires, 2005).

[15] D. Delizoicov, J.A. Angotti e M.M. Pernambuco, Ensino de ciências: fundamentos e métodos (Cortez Editora, São Paulo, 2007).

[16] F.S. Silva e F. Catelli, Revista Brasileira de Ensino Física 41, e20190029 (2019).

[17] M. Armatte, Mathematics and Social Sciences 43, 91 (2005).

[18] https://archive.mcxapc.org/docs/ateliers/lemoign2.pdf.

[19] M. Armatte e A.D. Dalmedico, Revue d'histoire des sciences 57, 244 (2004).

[20] M. Pietrocola, Investigações em Ensino de Ciências 4, 213 (1999).

[21] L. Cudmani e J.S. Sandoval, Caderno Catarinense de Ensino de Física 8, 193 (1991).

[22] C. Larcher, em Actes du séminaire de didactique des disciplines technologiques 1994-1995 (ENS, Cachan, 1996).

[23] J.L. Martinand. em Actes du séminaire de didactique des disciplines technologiques 1994-1995 (ENS, Cachan, 1996).

[24] J.P. Astolfi e M. Develay, A didática das ciências (Papirus, Campinas, 1995).

[25] L. Galagovsky e A. Adúriz-Bravo, Enseñanza de las ciências 19, 231 (2001).
[26] M. Pietrocola, em Ensino de Física: conteúdo, metodologia e epistemologia numa concepção integradora (Editora da UFSC, Florianópolis, 2001).

[27] J.F. Custódio e M. Pietrocola, em Atas do VII Encontro de Pesquisa em Ensino de Física, (Sociedade Brasileira de Física, Florianópolis, 2000).

[28] S.B.Concari, Ciência \& Educação 7, 85 (2001).

[29] T.F. Pinheiro, M. Pietrocola, J.P. Alves-Filho, em Ensino de Física: conteúdo, metodologia e epistemologia numa concepção integradora (Editora da UFSC, Florianópolis, 2001).

[30] J. Machado, K.S. Vieira, em Atas do XI Encontro de Pesquisa em Ensino de Física (Sociedade Brasileira de Física, Curitiba, 2008).

[31] S. Kapraz, G. Queiroz, D. Colinvaux e F. Creso, Investigações em Ensino de Ciências 2, 185 (1997).

[32] A. Cupani e M. Pietrocola, Caderno Catarinense de Ensino de Física 19, 96 (2002).

[33] C. Oliveira, Dicionário Cartográfico (IBGE, Rio de Janeiro, 1993).

[34] L.C. Pais, em: Educação Matemática: uma introdução, organizado por S.D.A. Machado (EDUC, São Paulo, 1999).

[35] R.J. Richardson e J.A.S. Peres, Pesquisa Social: Métodos e Técnicas (Atlas, São Paulo,1999).

[36] M. Lüdke e M.E.D.A. André, Pesquisa em Educação: abordagens qualitativas (EPU, São Paulo, 1986).

[37] R. Moraes e M.C. Galiazzi, Análise textual discursiva (Editora Unijuí, Ijuí, 2007).

[38] F.S. Silva, F. Catelli e O. Giovannini, Caderno Catarinense de Ensino de Física 27, 7 (2010).

[39] H.A. Simon e A. Newell, Models: their uses and limitations (The University of Chicago Press, Chicago, 1956). 